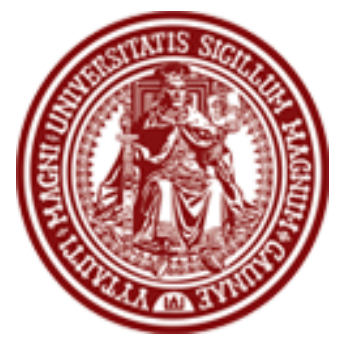

BALTIC JOURNAL OF LAW \& POLITICS

VOLUME 2, NUMBER 1 (2009)

ISSN 2029-0405

http://www.versita.com/science/law/bjlp

Cit.: Baltic Journal of Law \& Politics 2:1 (2009): 35-57

DOI: $10.2478 / \mathrm{v} 10076-009-0003-y$

\title{
THE ROLE OF EU LAW AND CHRISTIAN VALUES IN PRESERVING NATIONAL IDENTITY IN THE CONTEXT OF GLOBALISATION
}

\author{
Robertas Pukenis \\ Assistant Professor; Rev. Dr. \\ Vytautas Magnus University Faculty of Theology (Lithuania) \\ Contact information \\ Address: Gimnazijos str. 7, LT-44260 Kaunas, Lithuania \\ Phone: +370 37205489 \\ E-mail address: rev.pukenis@takas.It
}

Received: June 14, 2009; reviews: 2; accepted: July 15.

\section{ABSTRACT}

The aim of this article is to analyse how in the globalisation process small nations appear in danger of disappearing. Can law protect national identity when the state is in the European Union?

Globalisation together with the economic interests of states touches other spheres of society: national internal policy, education, mass media, the policy of family, migration. The birth rate in families in such big nations as Germany, France, and Italy is small. If numerous Italians, French, Polish, and Russians are worried about the constantly decreasing number of their inhabitants, no doubt that small nations are in danger of assimilation.

The European Union is an unprecedented formation of law: states retain their independence and at the same time people by their free will limit the sovereignty of a state. The $57^{\text {th }}$ Article of the EU Constitution clearly states that "the Law of the Union is higher than the national [law]." It is as if the European States are united in the form of a federation, though the concept of a federation state cannot be applied strictly. The first condition for each new candidate state is to be a democratic and law-based state. The law-based state means legal elections, authorities elected by the people, separation of three state functions (legislative, executive and judicial), respect for human rights, protection of the rights of 
national and religious minorities. Good relations with neighbours are always appreciated. The new EU constitution contains 400 pages. The Constitutional Agreement or EU Constitution was approved by the Council of the European Union in June of 2004. Each state ratifies the Agreement. Some EU countries plan the referendums. The Parliament of Lithuania refused the referendum. It was planned that the Agreement will come into force in 2009. The Constitution of the EU requires that the National Governments of Member States will not interfere in implementing the aims of the Union. The $58^{\text {th }}$ Article deals with loyalty to the Union. The institutions established by the EU work with human points of view and have a society model which is supported by the majority of the citizens.

In this article an attempt will also be made to evaluate the role of Christianity and its values for the legal system of the EU as well as for preserving national identity.

\section{KEYWORDS}

Globalization, national identity, European Union law, Christian values 


\section{INTRODUCTION}

In this article I would like to discuss the survival of small nations in the complicated globalisation process by analysing not only the legal system of the European Union but also by turning to the national identity of small nations. Let us try to imagine how much the law can help in preserving Lithuanian national identity in the context of the $21^{\text {st }}$ century's development of the European Union and what is the role of law in cherishing national culture?

National identity is inseparable from national culture. Every human being wants to know the origins of his nation, native tongue, history of the land that he calls his Homeland. He wishes to be the one having a national identity introduced by God into his personal nature.

Culture, which is composed of science, art, religion, the cherishing of national habits and traditions, and also the protection of rights of national and religious minorities, describes national identity in the best way. We perceive culture as the space of existence, and the earth is a small planet of people.

Each statesman or public actor should have the strategy of national survival. The nation, like a human being, has the birthright to be free, to create the model and the faith of its state independently.

The history of small nations is often greatly marked by spots of blood. Lithuania was occupied by Russian Tsars for 124 years, and after regaining independence in 1918 it had only 22 free years. In 1940 by the agreement of Stalin and Hitler was occupied again. Only in 1990 Lithuania, Latvia and Estonia managed to fight the most strongest and cruel empire - Soviet Union.

What destroyed the communist system which ruled half of Europe by leaving the prints of its character? There are objective and subjective reasons. Ronald Reagan, then President of the United States, Pope John Paul II, and Lech Walęsa, the President of Poland, winner of Nobel Peace Prize, and leader of SOLIDARITY all played a special role in breaking the Berlin wall.

The vital elements that broke up the soviet bloc were national movements and religious rebirth, the aspirations of independent decisions of nations and intensified protection of human rights, centralised and planned state economy (there was no free market), also military competition with huge budget means. As a result there were people in poverty and members of the elite political party who lived well and sometimes even competed with capitalists with property and luxury. The representatives of social realism had the attempts to overwhelm all spheres of human creativity by ridding the Soviet Union of culture and effectively falling 
behind much like a third-world country. The Soviet Union was destroyed because nobody kept faith in the law.

The main law of the socialist bloc was the superiority of the state when a human being serves the state. Millions of people died, with no traces of camps; the Kremlin tried to keep the accident in Chernobyl a secret for several days despite of big quantity of radiation, etc.

While in a democratic world the law prevails that the state has to serve the wealth of a human being. The law has to provide justice. By keeping these principles nowadays European nations with different historical experience, economical development and cultural heritage are under the process of uniting. The preamble of the Law of EU says: „The activities of the European Union should serve a human being by taking into consideration the necessity to make the process of European integration and the functioning of European institutions more effective, transparent and more clear to the citizens of the Union."

Thus the object of this article is the analysis of national identity in the context of globalisation and the role of EU law and Christian values in preserving it.

\section{SOME OUTCOMES OF GLOBALISATION}

What is globalisation? The Latin word globus means the earth, or universality. Looking at the current world we notice two main tendencies: globalisation and antiglobalisation. With greater economic challenges and advancements, the ensuring of security of the world in the $21^{\text {st }}$ century is possible only when uniting the efforts of states. United intergovernmental efforts and cooperation is necessary to control the criminal world. Globalisation tries to unite economic, human and natural resources. Newly forming blocks often unite the existing zones or create new economic zones in the form of increasing economic cooperation. The formation of the EU, the expansion of the NATO block could also be, to some extent, regarded as globalisation of a new world.

What are the aims of united Europe in the $21^{\text {st }}$ century? Such answer is given: "Europe's mission in the 21st century is to:

- $\quad$ provide peace, prosperity and stability for its peoples;

- $\quad$ overcome the divisions on the continent;

- $\quad$ ensure that its people can live in safety;

- $\quad$ promote balanced economic and social development;

- meet the challenges of globalisation and preserve the diversity of the peoples of Europe; 
- $\quad$ uphold the values that Europeans share, such as sustainable development and a sound environment, respect for human rights and the social market economy." ${ }^{1}$

Together EU states can bravely and efficiently manage the events and initiatives of activities important to the whole world and especially Europe which were declared in 2002 in Johannesburg during the World Summit: that is, the resources of energy, food security "the principle of caution", the aspects of ethical biotechnologies and environment protection - the necessity to protect vanishing kinds of flora and fauna. In 50 years EU institutions have a clear and improved programme - the position on important questions for ordinary people. 'A safe, united Europe' is a kind of soul of the introductory words of regulations of the United Nations: " ... again to fix the belief in the main human rights, the human dignity and value, equal rights of men and women, also big and small nations ...." At present our united Europe is strong enough to influence final decisions. The EU is one of the most important trade partners in the world, which is why it has a decisive word in international negotiations, for instance, in the World Trade Organisation uniting 149 countries or in implementing Kyoto Protocol concerning air pollution or climate change.

The aims of EU are important and just, but can they be practically implemented? Rather often the position of the inhabitants of one country is compromised by the division of politicians who damage or burden the achievement of a common aim - the qualitative and quantitative growth of the EU that will help form a strong federation. The continent where two world wars happened, with a diversity of political movements and confessions, differs much in comparison with the USA, which was established by the inhabitants of 13 colonies of the same faith and even of the same language.

Nevertheless, we cannot deny that a clash of interests among the states also exists in this democratically formed union. France and Germany approved the Russian position concerning the war of the USA in Iraq, and England remained a loyal ally of Washington! Also in this case, mostly, economic agreements dictate foreign policy. The old saying "unity - power" should be more relevant for Europeans now than ever.

I would like to stress that the unity of the EU in the best meaning is especially important, since a divided Europe will not be able to compete with the growing capacities of China and India; alone it will not manage the spreading terrorism which is more and more aimed at European Christian culture.

\footnotetext{
${ }^{1}$ Why the European Union? // http://Europa.eu/abc/12lessons/lesson_1/index_en.htm (accessed March 02, 2009).

2 Pranas Kūrys, ed., Suvienytuju Naciju Organizacijos Istatai. Tarptautinio Teismo statutas (Vilnius: Mintis, 1981).
} 
Today small nations of faith are included into the context of globalisation when many important institutions of one state are united and become dependent on international structures. The world is becoming smaller and smaller when states become dependent on each other and various forms of cooperation appear. The $43^{\text {rd }}$ (used to be 52) Article of the Agreement of Economical Community guarantees the possibility for working people and companies to start activities in the territory of EU. They themselves choose the plane of living and acting in EU. ${ }^{3}$ Three directives: free movement of people (EBS 39-42), the right to establish companies (EBS 43 48 ) and the right to provide services (EBS 49 - 55) promotes the movement of people in EU rapidly. The most important is that the Declaration concerning the explanations of the Charter of the Main Rights (2006-10-23) prohibits the discrimination of persons working abroad due to their citizenship, employment, working conditions and salary. The more open the walls are, the less barriers among states we have, the more vital economical potential is and the life of nations and people is more efficient. True, we can doubt if people who have just left the Soviet bloc with no experience with free market principles will manage to reach the same results in business as those who have worked in a free market context for fifty years already? That is why EU institutions provide support for newcomers, so that they can catch the old members.

Citizens of EU member states can travel, live and work any place in Europe. Thus, the citizens have all possibilities in order to choose and use their skills and capital as efficiently as they can in business. When "the walls are open" people of each state have the same right to go and legally work outside their homeland; they also have the same social guarantees and can develop cultural life together in the land of their new faith. Almost half of the Lithuanians who have left the country will remain abroad forever, making families with people of other nationalities. They will never come back to their homeland, since humans naturally search for a better place and a better life. In such a way small nations without any pressure can melt into the areas of big states. ${ }^{4}$ In seventeen years of independence $0.5 \mathrm{ml}$. Lithuanians have left and only 80.000 came back. Last year, in 2006, 27.800 residents left Lithuania. ${ }^{5}$ Already this demographic crisis has had tragic consequences in the public life of Lithuania.

\footnotetext{
${ }^{3}$ Skirgailè Žaltauskaitè-Žalimienè, Laisvas asmenu judèjimas pagal Europos Bendrijos Teisę: Isisteigimo teise (Vilnius: Rosma, 2002), p. viii.

${ }^{4}$ In almost half a year the number of Lithuanian inhabitants decreased to eight thousand. According to the data of statistics, in the beginning of June there were 3437900 inhabitants in Lithuania- 8 thousand less than in the beginning of the year. In Lithuania death rate is bigger than the birth one: in 2007 in five months 17753 people died, 12356 were born.

5 Darbo migracijos ypatumai- veiksniai, pasekmés ir tendencijos - Kauno mieste (Kaunas: Spaudos namai, 2007), p. 6-7.
} 
Globalisation raises problems of different kind. Gedas Malinauskas, representing the Social Work Institute of Vytautas Magnus University, did a survey in the City of Kaunas and found out the problems which were not counted before, "that is the leaving of both family partners by leaving children to relatives, mainly to grandparents". According to G. Malinauskas, "the couples leave and they are not ready for separation, - psychological communication difficulties appear among partners themselves and among parents and children. ${ }^{\prime \prime}$ One third of respondents declared to the survey maker that "it was not so hard to work abroad physically, but emotionally it was. One-fourth felt a negative impact of work migration on their family. Part of expectations are not realised not only because of work and living conditions but also counting the difficulties when coming back."

When so many Lithuanians left to go abroad, spiritual emptiness became opened up. This is the situation described by professor Ona Voverienè: "There is no nation of Lithuanians in Lithuania. There is no will of it ... The balance between the government and the nation is violated. ${ }^{8}$ Yesterday totalitarian regimes violated the personal growth and national traditions in one way, today, when we are in the EU, national identity faces other dangers. Several public actors notice that maintenance of national identity is becoming of vital importance. "When regaining independence the public hoped for the creation of national state which could cover the strengthening of national identity. Though, the state was separated from the national content, and the name of state institutions were influenced by the guidelines determined by euro integration processes." ${ }^{\prime 9}$ "Material base was destroyed, independence abolished, political class was taken out - thus national state becomes a simple security office of mega companies. There is no need to rule directly for the new masters of the world. National governments are committed to administrate the matters for their needs."10

By enabling economic inter-governmental interest globalisation touches other public fields: national internal policy, education, mass media, family policy, migration. Already now clear demographic changes are the reality in Western Europe. In some French cities one-fourth are the believers of Islamic religion. Islam is the second religion in France, Italy, and Germany. Emigrants coming from other

\footnotetext{
${ }^{6}$ Ibid., p. 13.

7 Ibid., p. 20, 21.

8 Ona Voverienè, "Po didelio triukšmo priedanga dar vienas bandymas užvaldyti valstybę," Lietuvos Aidas 92 (2007 04 24): 9: "Lithuania does not have youth. Only 9, 4 percent of Lithuanian people of 1830 years old go to vote, fulfil the duty of citizens. Where are the others? Also they do some violence, in a year over 5000 crimes are made ... They do not exist in political environment ... ."

9 Juozas Paškevičius, "Melo kojos trumpos, arba kam reikalinga Europos Sajunga?" Laisvas laikraštis 11 (2003 05 22-06 05): "Where Lithuanian identity and independence won in such a hard manner is -was it only because of leaving one Union we could enter the other one?"; Marius Deksnys and Paulius Tamulionis, "Europos Sajungai - miglota Lietuvos ūkio strategija," Lietuvos rytas 212 (2001 09 11): 10; Vytautas Rubavičius, "Gynybinis klausimas - nacionalinio tapatumo savikūra", Baltijos kelias 11 (2006 07 04): 13.

${ }^{10}$ Algirdas Endriukaitis, "Atsišaukimas, Rankraštis," (2005 01 31): 1.
} 
countries increase the number of inhabitants but not of their own nation. In big nations as Germany, France, Italy the birth rate is low. Small nations are in danger of assimilation to the bigger countries such as Italy, France, or Poland.

An unbalanced emigration policy provokes tension in societies and in some countries unhealthy national manifestations - hatred towards emigrants, riots, and the burning of houses. History says that cosmopolitanism, which could be implemented by EU ideologists, can provoke national movements of extreme forms harmful to the EU. Those who wish to create citizens of Europe without traditions and religion may destroy the European Union itself. That is why such concepts as homeland, nation, national and religious traditions, language, historical roots, and cherishing of national culture must not be led to disappear. Some EU politicians who have introduced the concept of a European citizen should not forget the native law that if a person does not love his homeland then he will not be able to evaluate and cherish the spiritual heritage of other nations, tolerate others, or accept those who think differently. Each human being first of all has the right and duty to develop his own national culture: language, habits, religion. Being the one you are you will be able to evaluate the spiritual features of other nation, be open to other cultures, democratic and tolerant.

The EU is the union of legal states and a legal state does not take human freedom away; it even protects them individually and keeps them in separate communities. Only a conscious human being will be able to use the provided rights without violation the laws of the state.

We perceive law as the system of rules giving directions how to live, and protecting the society and each person from evil. Law influences the development of a state by escaping from conflicts, describing and uniting all citizens into one common aim and by respecting the personal freedom of all persons. If it is hard to do so in the territory of one state, it is even harder when 27 states unite. It is necessary and important, especially in large EU cities, to open various centres where the experts could advise, provide information about EU structures, foreign and internal policy, cultural cooperation, support for economical development, protection of heritage and so on in order to have formed mutual connection between nations. ${ }^{11}$

The EU will become stronger and will have a more real future, if it manages to solve national problems. If all legal system from one side is able to eliminate unhealthy national manifestations, radical anti-global tendencies, from the other

${ }^{11}$ We can mention at least some of them: Public Institution the Centre of Translation, Documentation and Information, Public Institution European Social, Legal and Economical Projects (ESTEP), etc. 
side the policy of each state will promote and cherish national identity of citizens by fostering openness to the unity of European nations.

After long studies and hard lingering discussions, after subjective doubts and objective reprimands, I dare to state that the European integration process has not overwhelmed the many-sided lifestyle of Europeans, their traditions and cultures. Diversity is one of the main values of the EU. The disappearance of one or other nation is the problem of it own - inability to protect itself, a situation without leaders, or the inability to fight negative factors. So, what are the values uniting European nations?

\section{WHAT UNITES EUROPEAN NATIONS?}

Law. The European Union is an unprecedented formation of international law: the states protect their independence and at the same time the people, by their free will, partially limit the sovereignty of the state. The $57^{\text {th }}$ Article of the EU Constitution clearly states that the "Law of Union is higher than the national one". In such a way United Europe in the form of a State Federation is created, though the concept of federal state cannot be applied strictly.

The EU is created in regard to international law norms and rules, and that determines the legal system of the European Union. An ordinary human being cannot understand it properly up to the end. Nevertheless, it is necessary to explain what is done in the complicated process of activities to the majority of citizens. It is the necessity of united Europe; it also means economic development, wealth of all nations, cultural cooperation and peace in protecting themselves from any hits and from anywhere... "The fear of totalitarianism has disappeared, though instead of it we notice other fears which cannot be foreseen in advance. This situation is purely new even for Church. Pressure of Communism showed the way to it, provided the sense of reality which is crumbling today", said the Archbishop Carlo Maria Martini. ${ }^{12}$

The first condition for each new candidate is to be a democratic and legal state. The state of law means legal elections, legally elected authorities, separation of three state functions (legislature, executive and judiciary), respect of human rights, and protection of rights of national and religious minorities. Good contacts with neighbours are appreciated. Though, "good contacts" should be understood relatively. Latvia did not have good contacts with Russia but nobody stopped it from becoming the member of EU. The candidates that have the features of legal states, the citizens of which approve the membership, become the member of EU.

\footnotetext{
${ }^{12}$ Feliksas Kairys, "Žodžiai smèlyje," Naujasis Dienovidis 20 (1994 05 20): 10.
} 
The most important treaties of the EU are the Rome Treaty, the Single European Act, and the Treaties of Maastricht and Amsterdam which became the main legal basis of EU formation and communication. An EU member is a state which has signed the Treaties on the Establishment of European Community and EU. The countries having not been among the state-founders signed the Treaty of Entrance and at the same time joined all earlier treaties. Before entering EU each state had to "adjust", change, to equal the laws. Each national legal system had to conform to the already existing legal criteria of united Europe. It opens a titanic space where a person and nations can realise their economic, political, cultural aspirations. There are lots of advantages: free movement of people, goods, capital and services - all this opens bigger possibilities to the economy of each state. Common EU foreign policy and military power, united system of duties gives the possibility to create free union of European Union. The largest task remains - the creation of free human beings, responsible for their state. With their aspirations and souls they should belong to one big European State and at the same time should remain loyal to the national culture of their nations and should not lose national identity.

At last, EU states have decided on the main norms of EU Constitutional Treaty. The present composition of EU Constitution is comprised of diversity of treaties. It is complicated not only because of the "pillar" structure introduced by the Maastricht Treaty but also because of oft-changed three Establishment Treaties of European Community. The beginning was Amsterdam Treaty - the old regulations were eliminated, terminology became the same, amendments were made and lastly, the numbers of articles of EU and EC Treaties. The new document consists of 400 pages. Constitutional Treaty or the Law of EU was approved in June of 2004 by EU Council of Heads. Each state has to ratify the Treaty. Some EU countries have decided to lead referendums concerning the Constitutional Treaty. Lithuanian Parliament has refused the referendum. It is planned that the Treaty will come into power in 2009. "By the help of Constitutional Treaty all existed treaties of establishment will be united, a united, more clear document with less complicated procedures and allowing easier decision making will be created,"states ex-negotiator on European Affairs Petras Auštrevičius. The political aim of "simplifying" of treaties is to get more public support for further integration.

There are five main innovations which will improve the functioning of EU institutions: 
- Most of the decisions will be made by the qualified majority, and the principle of unanimity is left only for some cases. The states with more population will get more influence. ${ }^{13}$

- The leaders of states will unanimously elect the Chair Country for two years period with the right to be re-elected. The existing rotation principle of Chairmanship will disappear;

- For the period of five years the Foreign Minister of EU will be elected. He will be responsible for the common foreign and security policy of the block. It is hoped that this duty will help to increase the influence of EU in the world;

- The Charter of the Main Human Rights which will become a must to all member states will be involved into the legal system of EU. ${ }^{14}$

- EU is comprised of five fundamental institutions: the Council of European Union, European Commission, European Parliament, the Court of Justice and the Palace of Audit. ${ }^{15}$

EU constitutional norms do not eliminate national institutions and do not limit their activities. The $58^{\text {th }}$ article/3 of EU Constitution approves that "Union respects national distinction of member states, their constitutional and political structure and their competence and is loyal to them."

Maastricht Treaty which is included into the articles17-22 of the second part of EC Treaty has determined citizenship. The citizen of each member state is the citizen of EU and those do not having citizenship in their living country cannot also be the citizens of EU. EU citizenship adds national citizenship but does not change it. Each member state determines citizenship by their own criteria that is not violating the Law of the Community determines the conditions for getting and loosing citizenship as it was done earlier. EU citizens have the rights and duties determined by the Maastricht Treaty. The main rights are as follows:

- The right of movement and the right to choose the constant living place in the territory of EU countries;

- The right to vote and be the candidate to the elections into European Parliament and local authorities in their constant living place in the member state;

- The right to diplomatic and consular security;

- The right to apply the European Parliament with a petition;

- The right to apply the Court of Human Rights in Strasbourg.

\footnotetext{
${ }^{13}$ Qualified majority is the majority consisting of at least 55 percent of all state members, though not less than 15 representing at least 65 percent of all EU inhabitants.

14 Lietuvos Respublikos Seimo Europos Informacijos biuras, Sutartis dèl Konstitucijos Europai // http://www.eic.Irs.It/index.php?1959708497 (accessed March 02, 2009).

15 In 2014, the number of members of European Commission will be decreased. It will consist of two thirds of representatives of all state members.
} 
As we see there is no direct purpose for the equality of all EU citizens in legal doctrine. Only circumstances, human character, and the policy of own national government towards emigrants (if education, the contacts of emigrants with the Homeland) could act here.

So, the activities of EU institutions should all the time have two directions or two unified points of view. EU Law describes general guidelines; directives by the help of which the institutions of intergovernmental cooperation of all fields are united and at the same time form the human mentality and life style of new Europe. In other words, it unites people in their soul, traditions and values. Italian professor of international law V. Buonomo describes the processes in the EU as an ally looking for identity, first of all, for a legal one, later for an economical, historical and European cultural. In diversity unity appears. ${ }^{16}$

Humanistic values and aims. EU Constitution binds the governments of member states to take necessary means or not intervene in implementing the aims of the Union. $58^{\text {th }}$ Article deals with loyalty of the Union:

1. In order to ensure the implementation of the duties determined by the Constitution or Union Actions, member states take all necessary common or special means. They help to carry out the tasks of the Union.

2. Member states do not take any means which could disturb the implementation of aims and rights foreseen in this Constitution.

EU institutions promote humanistic and advanced values and try to ensure that the biggest changes of the world could be useful and not harmful to humankind. Today no country will succeed in satisfying the needs of nations and people only by the rules of the free market or the separate actions of one country. The Governments of EU countries promote and donate the programmes of mutual cooperation of citizens in different fields and especially in education and culture.

The institutions established by the EU have a humanistic point of view and support a model of society which is supported by the majority of citizens. The introduction of EU Constitution says: "By perceiving our common spiritual and moral heritage and inseparable overall values of human dignity, freedom, equality and solidarity, by approving our own fidelity to the principles of freedom,

\footnotetext{
16 La relazione del Profesore Vencenzo Buonomo alla Conferenza a Kaunas: „L'attenzione, dunque, è posta su un concetto di identità compatibile con l'elemento giuridico ed istituzionale, ai diversi livelli, nazionale/statale, internazionale, europeo, ma cercando di leggere le diverse situazioni come parte di un percorso unitario e non come momenti separati o addirittura contrapposti".

From the presentation of Prof. Vencenzo Buonomo at Kaunas conference: "The attention is given to identity complying with the legal institutional element at all levels: local, national/state, international European. Though the analysis is done on various situations as part of the integral job implemented but not as separate or even different one." (Vencenzo Buonomo, L'unita dell'Europa. Tra integrazione e tutela delle identita' [The unity of Europe. Between the integration and protection of identity]; La relazione del Profesore alla Conferenza a Kaunas il 10 novembre 2006," [The presentation of Prof. Vencenzo Buonomo at Kaunas conference 1011 2006]).
} 
democracy and respect to human rights and main freedoms and the principles of legal type ... ." Europeans preserve inherited values: human rights, social solidarity, the freedom of establishments, the proper division of fruit of economical growth, the right to protected environment, respect to different cultures, languages and religions, the harmony of traditions and development.

All rights today used by the member states of EU and their citizens are depicted in the Charter of the Main Rights proclaimed in Nice in December of 2000. These values can unite Europeans. One of the examples is prohibition of the death penalty by all EU countries.

Christian culture. It mostly unites the nations of Europe. Historically Rome was the cradle of Christianity, and the empire of Rome left its prints in architecture, art and Christian humanism. Christian culture was formed here; the cities were decorated by the most beautiful Cathedrals, Basilisks. It is hard to imagine Europe without Christianity. According to Jacque Mari, it is religion which teaches to forgive, is the most tolerant, the founder of which Jesus Christ is the father of full humanism. That's why it is a pity when politicians, thinking that they are Christians, are not able to evaluate the essence of Christianity and take part in inter-religious dialogue. The inhabitants of Europe open the gates of support for refugees for far away countries that they could honour the God by living here as any religion faces the same Lord of the world. Why do our politicians not demand from the leaders of African and Asian countries that Christians in their countries be allowed to freely build churches? Each Christian respects the traditions and culture of people living in other lands and does not dictate any conditions for the people in their homeland. Our Europe shows paranoiac manifestations for instance when schools of South Italy took out crosses, and when people are afraid to offend other believers or nonbelievers. Why is Christian belief guilty when other believers hospitably welcomed here that they require, teach and order to change traditions?

The Union of EU nations into one family, its prosperity and protection of our common space from dangers depends on a new generation of politicians able to understand and solve problems, just as Robert Shuman in France, Winston Churchill in England, Conrad Adenauer in Germany and Alcide De Gasperi in Italy used to do. Each European respecting oneself should feel honour and duty to protect and cherish Christian heritage. Belief in common wellness, cherishing of national traditions and human spirit will unite nations by spiritual ties; it will let them communicate and understand each other during the conditions of competition. Let us not be afraid to pronounce the word "religion" as a sacred human duty to God and homeland. It is worth recalling the teachings of John Paul II: Europe has to return to Christian traditions, to our own sources, so that people 
of different and often contradictory continents can feel common soul, history, would like to protect each other from common danger and create nice and safe future. That is why the Throne of Apostles tries to develop inter-religious dialogue, cherish peace and tolerance, and respect human rights. No doubt, keeping the law should come together with rights, and the implementation of duties to the state where you live. The created love civilisation is perceived in this way by John Paul II who did so much for the European unity. ${ }^{17}$

We all Christians will try to attract the attention of European architects and evaluate Christian heritage in a proper way. Youth has to understand the real ideology of freedom and advancement satisfying human hopes and helping to create full humanism on Earth. In two thousand years Christianity formed experience and common features of European nations: traditions, culture, family traditions, the same spiritual values. This is the basis for spiritual unification.

\section{THE PROBLEM OF NATIONAL IDENTITY}

The preamble to the Constitution of the Republic of Lithuania sounds like a hymn of the nation:

\section{THE LITHUANIAN NATION}

- having created the State of Lithuania many centuries ago,

- having based its legal foundations on the Lithuanian Statutes and the Constitutions of the Republic of Lithuania,

- having for centuries staunchly defended its freedom and independence,

- having preserved its spirit, native language, writing, and customs,

- embodying the innate right of the human being and the Nation to live and create freely in the land of their fathers and forefathers-in the independent State of Lithuania,

- fostering national concord in the land of Lithuania,

- striving for an open, just, and harmonious civil society and State under the rule of law,

by the will of the citizens of the reborn State of Lithuania, adopts and proclaims this CONSTITUTION.

Lithuania already in the $16^{\text {th }}$ century was a legal state. In 1529 the Parliament of Nobleman in Vilnius approved the Code of Laws of the Lithuanian state -

\footnotetext{
17 Gino Petrilli, "Le radici comuni cristiane della fede nello spirito europeo" [Common Christian roots in religion and European spirit]; in: Pontifical Lateran University, Catholic University of Lublin, The Common Christian Roots of the European Nations (An International Colloquium in the Vatican, Florence, 1982), p. 1288.
} 
Lithuanian Statute which appeared earlier than Russian or Polish Statute-books and was widely used. ${ }^{18}$

Lithuania is famous for tolerance of other religions and nations. Lithuanians sheltered the old believers when the Tsar started persecution of them. Students of different nations studied at Vilnius University established by Jesuits in 1579 . Vilnius used to be the third Jewish Jerusalem. We could not stop the war and killings started by Germans, and we very much condemn those who started the holocaust. Let home be comfortable first of all to those who have lived here for a long time. Today the Law of the Republic of Lithuania protects the rights of people belonging to national and religious minorities, they have the right to develop national culture: learn mother tongue, cherish traditions and practise religion.

The $12^{\text {th }}$ Article of Law on international treaties of the Republic of Lithuania of 1991 says: "International treaties of the Republic of Lithuania have the power of law in the territory of Lithuania". It is perceived that each legal state by approving the principles of international law cannot break these treaties without essential background. We cannot destroy the legal basis which allows our participation in EU life and activities.

In 1995 when Lithuania signed the Association Treaty with EU about 1000 laws were changed in the whole national system of law. (Lithuania abolished the death penalty; it will make easier the process of land buying for foreigners). Before entering EU the whole legal system of Lithuania was looked through and adjusted to EU legal norms (of course, there are still some things to be solved technically but nobody could deny the way the nation has chosen to belong to EU). The legal norms taken by our own will cannot be rejected unless it harms national interests. In such a case all interests are coordinated during the Meetings of European Parliament and the work of commissions. In spite of the fact that EU law is higher, if a citizen or a state has some damage, national governments usually protect their interests. Let us say the French national radio orders that half of broadcasted songs have to be French, the remaining part may also be foreign songs.

"In contrary, we need very strict "protectors" in limiting the selling of land in reservoirs, by lakes or by the sea. For example, Latvia for already some time has opened the market of land for foreigners without any doubts and experienced their aspirations to buy only the land by the sea around Jurmala. Actually other countries and even the nowadays member states of EU protect the lands of rest zones very much, and does not sell it easily." ${ }^{19}$

18 On the Statute of Lithuania see Vytautas Landsbergis, "Vejantis prarastą laika," Dienovidis 29 (2000 12 8-21): 2.

${ }^{19}$ Lina Pečeliūnienè, "Europos Sajunga geriau už "šventaji kara"," XXI Amžius 13 (2002 02 15): 8. 
Today the line of some left wing politicians is directed towards of damage of the nation itself. Many critical voices can be heard about the Parliament (the Seimas): the Seimas has changed the $119^{\text {th }}$ article of Lithuanian Constitution regarding the participation of citizens in self-governing and management. Side by side with the word "citizens" appeared the insertion "and other inhabitants of constant administrational unit" in the Constitution. According to the Constitution only the citizens can elect and only the citizens can be elected into the Councils of Cities. In regard to a Communistic scenario, after the change of Constitutional Article, non-citizens can be elected. Those who are not wishing to take the citizenship; they are mainly against the state of Lithuania. Such inhabitants are allowed to come to state institutions! Some do not know Lithuanian, others used to be autonomists. The authors of this scenario explain that it is ordered by the Directives (94/80/Eb) of EU Council. The EU Directive, for example, allows the Germans living in France to take part in elections. It is pure logic - he/she has German citizenship, has rights and duties. Here, if one does not have citizenship he is a stranger, in most cases the citizen of a third country, without rights and duties to Lithuania. He has no need to get the citizenship because he can never take part in elections. It could soon happen that such people who do not like Lithuania, strangers, could be elected to the Seimas. There are no words to express it, no legal logic. It means that national politicians can adjust the same EU legal norms in the way they wish. All this requires active care from citizens and advanced political parties.

The Apostolic Nuncio Archbishop Peter Stephan Zurbriggen said in giving a speech at Kaunas Vytautas Magnus University on November 10, 2006, in opening the conference "Protection of National Identity in EU": "My short mentioned aspects about spiritual and cultural heritage of Lithuania highlight and at the same time make the base for national identity. I hope that Lithuanians will manage to protect and take care of their own national identity, will not be mistaken by indifferentism or relativism, will not become dependent on conformism, which assimilates everything and everybody on European level, tries to impose the norms of social behaviour clearly contrasting spiritual cultural tradition which was left by Europe as big, nice and exemplary one," spoke the Nuncio.

Lithuania all the time was looking back to Western culture. According to A. Maceina, "past history remains in nation as testimonial heritage, it is told to coming generations anew and they add to it their own input in such a way that a tradition becomes a creation of constant national culture treasury. Human history is a history of a human's homeland. I cannot have my personal history which is not an 
imprint in the history of my Homeland."20 These words suit perfectly in describing national identity which comes with history. A human being wishing to protect himself and his Homeland makes certain solutions relevant to today and records his faith.

Lithuania is a legal state, a democracy and a Christian culture. Its culture and history have belonged to Western Europe since long ago and at present with determined legal ties it belongs to EU.

\section{EUROSCEPTICISM}

National movements which became strong at the end of the $20^{\text {th }}$ century tried to correct the results of globalisation. In such a way new independent states, e.g. 15 separate states were created out of one Soviet Union; out of Yugoslavia we have 6 separate states. Even Montenegro which has half a million of inhabitants during the referendum was for the separation from Belgrade. Czechoslovakia was also separated into two parts: the Czech Republic and Slovakia. The movement of Basques trying to separate from the Spanish nation is another good example. The conflict of Northern Ireland is mainly of national character with the aim to have Belfast in the Republic of Ireland. True, after the breaking of Berlin wall in 1989 the axis of conflict was re-grouped from East -West to North - South direction. So, it is dangerous not to take care of national movements.

Today two tendencies prevail in the world: globalisation and antiglobalisation. There are a number of euro sceptics in regard to EU and they add a negative point of view to the unity of Europe. The number of such new dissidents is increasing. They persistently and painfully remember the experience of the Soviet Union and cannot stand any Union at all. V. Bražènas, a well-known Lithuanian journalist, states in the announcement of National Front discussions: "The question of Homeland betrayal is valid also for those citizens of the Republic of Lithuania who silently go to the slave box of regional globalists of EU." ${ }^{21}$ Ex-dissident of Russia V. Bukovskis bravely encourages: "As soon we finish with EU, the better it will be. As soon it is destroyed, the less harm it will do to us and other states." ExSoviet dissident warns about the coming threat of dictate of European Union: "When you look at the whole activities of EU covered by the text of 80.000 pages, it reminds of Gosplan."22

Each state rather often refuses sovereignty for the sake of EU. The policy implemented by EU institutions provokes great mistrust, dissatisfaction and

\footnotetext{
${ }^{20}$ Antanas Maceina, Asmuo ir istorija. Žmogaus istoriškumo prasmè ir vertè (Kaunas, 1992), p. 6, 12.

${ }^{21}$ Vilius Bražènas, "Lietuva pasaulinès krizès akivaizdoje," Laisvas laikraštis 5 (2007 03 8-22).

${ }^{22}$ Ibid.
} 
grounded fear concerning the consequences of losing sovereignty. An ordinary citizen usually can hardly guess when European Parliament Directives are by obligation and when they only give advice. Sometimes our own politicians simply do the things which are convenient for them. It is a serious reprimanding to European Parliament which is elected by proportionate representation election system and does not embody real national representation. V. Bukovskis compared the work of European Parliament with the role of the Supreme Council during the times of Soviet Union. ${ }^{23}$

Some despise the highest bodies of European Union and complain that they did not manage to form a common policy of EU in regard to Russia. These three reasons raise dissatisfaction in almost all EU member states in some national circles. It is doubtful if the EU will defend a small nation in reality. The events in Tallinn in 2007 showed that Moscow tested the West - is it unified, will it be able to protect Baltic States in the so called "near abroad" geopolitical sphere from new occupation and the power of Finland? The EU does not possess a common policy in regard to Russia. It is worthwhile to quote the words of Professor V. Landsbergis, the Member of European Parliament: "It is one more sign that the EU does not possess its own European policy in regard to Russia. What we have and implement is Russian European policy in regard to Russia. Indulgence of leaders is the worst service to Russia, if anybody still wants to believe that Russia could become a European country quicker than Europe becomes a political annex of non-democratic Russia. We constantly talk about unified European Energy Strategy but close our eyes when thinking that Russia will not let it happen and already has its Trojan horse in the middle of Europe. The lovers of Schroder and other politicians with political cataract further on continue the destruction of unified Europe."24 Let us remember the events of 2006 winter by the border of Latvia and Lithuania, and the queues of trucks at the customs' office. Lithuanian governmental circles tell that in this case, when Latvia closed the border with Lithuania and implemented coordinated policy with Russia, it could be counted as the representative of NIS but not EU. Inside EU there cannot be queues by borders and Russia by using Latvia creates cases with no analogues. ${ }^{25}$

On the basis of existing differences between the members of the Union, Russia divides Europe into "old" and "new" members and influences them 23 Ibid.

${ }^{24}$ Vytautas Landsbergis, "ES neturi europietiškos politikos Rusijos atžvilgiu. Kalba Europos Parlamento mažojoje plenarinèje sesijoje spalio 11 d.," XXI amžius 19 (2006 11.15).

25 "Užsienio šaliu ambasadu atstovai kviečiami i Lietuvos-Latvijos pasieni," BNS (2006 11 28) // http://www.politika.It/index.php?cid=9329\&new_id=247027 (accessed March 02, 2009).

Latvia does not wish to "uncork" the border with Russia: "Russia, controlling the majority of Latvian transit companies, is interested that Polish and Lithuanian carriers could have some troubles. In such a way the biggest part of transit will be done via Byelorussia which is not stable from the point of view of business." 
respectively. These are the concepts introduced by Donald Rumsfeld, taking into consideration the contacts of countries with USA. But V. Putin managed to use the ambitions of France and Germany in order to divide Europe, to make deeper hole between the old and new members. If European countries agree on common policy in regard to Russia, the initiative could be again taken by Europe as it is economically stronger than Russian Federation Republic. Greece and Cyprus are called "Trojan horses", as they usually support Russia. Germany, France, Italy and Spain develop strategic cooperation with Russia and do not care about common foreign policy principles of EU. Austria, Belgium, Finland, Slovakia, Portugal and still more five countries are the so called group of "friendly pragmatists". Their relations with Russia are not as close as those of "strategic partners", but rather wide and first of all have economical motives. There are still nine more countries: the Czech Republic, Latvia, Denmark, Switzerland and Great Britain belong to the so called group of "continent pragmatists". These countries also are interested in close economical relations with Russia, but rather often also criticise it for its violations of human rights and its lack of democratic principles. Finally, Poland and Lithuania are called the supporters of the strict line, and their relations with Russia are "openly hostile". ${ }^{26}$

From some of the aforementioned facts it is obvious that EU unity is external, formal or in many cases very fragile. Millions of citizens of a small nation can get disillusioned that the EU is not able to make common policy in regard to Russia and the USA.

Despite the existing differences and shortages there is a need to unite forces and improve Europe, to put it on a solid fundament of ideals. There is a need to unite Christian forces and to add some attractiveness to the unity of EU.

\section{REAL OR IMAGINED THREATS?}

The well being of the EU will partially depend on how much it can affect the psychology of Russian politicians and especially the whole Russian nation. Will the interests of states in non-convenient geopolitical situations be defended sufficiently enough? Will the EU struggle for unity and be ready to feel some economical disadvantages and yet not betray its commitments?

During the whole period of independent Lithuania (1990 - 2007) the grounded fear in regard to Russian political activeness has not left. It is only some thoughts from the language of Mr. Algirdas Katkus, one time Chairman of National Security and Defence Committee of the Seimas: "Only a very naive person could

26 "Europa skaldo Rusija," //

http://www.delfi.lt (accessed March 02, 2009). 
think that Russia has stopped its intelligence activities in Baltic States. Russian intelligence officers are the best prepared in the world. Moscow, by the way, will expand its secret activities and in the future and especially now when the West declared that Lithuania in several years can become the member of NATO." ${ }^{27}$ Russian spying in trying to get political and military secrets out of the USA reached a level which has not been seen since the times of the Cold war period. ${ }^{28}$ "Some states" in Lithuania practically wage an information war. The main fear is in direct finance injections into Lithuanian policy. All these processes are "a huge concern" and danger for the state of Lithuania. It should be considered not only by the State Security Department but also by some other state institutions; all national political systems should be considered. ${ }^{29}$ Sometimes the activities of the Head of the State or some Members of the Parliament make trouble or even turmoil, because it is not clear what purpose it serves. The famous dissident Antanas Terleckas applied to the nation because of an unclear position of the President: "Indifferent point of view of the nowadays President of the Republic of Lithuania to the existing political, economical and legal chaos in the state, open betrayal of the state were planned in advance." ${ }^{30}$

None of the politicians or public actors of the Baltic States feel (maybe not the same intensively) fear because of such situation. For example, the President of the Republic of Latvia V. Vykè-Freiberga in giving an interview to one popular German Daily declared that "she is greatly worried about Russian instability. The Head of Latvia also stressed that Russia is a strong danger for the independence of Latvia and the possibility of new occupation is very much a reality. ${ }^{\prime 31}$

The wish of part of Russian politicians to keep "near abroad" under their influence is pronounced openly. It is necessary to stress that the idea of a strong state in the mentality of the Russian nation plays an exceptional role, special Russian cultural peculiarities are constantly stressed (in contrary to the Western liberal democracy) and the civil power of the nation. This cultural-Messiah imperative forms a perception that the existing diminishing of Russian power is only a temporary phenomenon. The restoration of Russia as super state should start from the restoration of political influence in the states of "near abroad". Russia has never refused the ambitions to rule the world and this means preparation for energy, diplomatic or even hot conflict in order to regain the lost positions in these

\footnotetext{
27 Vytautas Kubilius, "Ar ilgai tvers mūsu Nepriklausomybė?" Dienovidis 7 (1995 02 18): 2: "The worst thing is that the society itself is not prepared for the forms of public resistance. On the contrary, ideological re-sovietisation is being implemented gradually."

28 "JAV žvalgybos vadovas sunerimęs dèl rusu šnipinėjimo," Elta (2007 03 29).

29 "A. Pocius: kai kurios valstybès Lietuvoje kariauja informacini kara" // http://www.delfi.It (accessed March 02, 2009).

30 Antanas Terleckas, "Sąmokslas prieš Lietuva, skaitytoju nuomonès apie Prezidento rinkimus?" Valstiečiu laikraštis 99 (1997 12 13): 8.

${ }^{31}$ Laurynas Kasčiūnas, "Didelis nerimas," Valstiečiu laikraštis 43 (2000 05 30): 5.
} 
states even partially. Today Russia in a short time has already achieved weighty results. On June 15, 2001, Moscow managed to create a cooperation system of security, economy and military. It is known by the name of Shanghais Cooperation Organisation. Russia forced Uzbekistan which earlier pretended to be the strategic partner of USA to return to this organisation. Russia has practically destroyed GUUAM (the organisation of Georgia, Ukraine, Uzbekistan, Armenia and Moldova) which was the alternative to NIS (without participation of Russia). At least, Russia managed to increase its influence in Ukraine and almost prove that the idea to create a common economic space is useful.

Laurynas Kasčiūnas described the situation very concretely: "In recent years the invasion of Russian capital (which belongs to the state or at least controlled by the state) to the strategic kinds of economy or its objects (energy, telecommunications, transport, etc.) of Middle Europe and post Soviet states has increased." ${ }^{32}$

Today new direct aggression as it was in 1940 could not be a reality; but there are some other means and ways to strengthen the Russian economy and later also gain greater political influence in Baltic States, - and it is being done very quickly. It is mainly done by the elimination of patriotic politicians or ideologues of the nations, by increasing negative influence of mass media and especially fighting the Catholic Church, by pushing politicians loyal to Russia into Parliaments and governments, and thereby destroying the unity of the Baltic States. Emigration to the West is also secretly promoted and the vacuum which will be needed to be filled by workers from Belorussia and Russia will soon appear in the Baltic economies. So, the real possibility to lose sovereignty exists.

\section{CONCLUSIONS}

EU grew into a titanic space covering almost all continent of Europe. Baltic States did not have and still does not possess any other way to be the member of EU which is comprised democratically in achieving the prosperity of nations. Despite of different points of view in foreign policy, the leaders of member states come closer in solving security problems and especially after the change of leaders (e.g. France, Germany). A long way of reforms, reforms of national law providing economical vitality and even prosperity for people has been taken in internal policy.

Side by side with positive results globalisation has also negative consequences though these are weaker than those against the unification of EU. Anybody trying

32 Laurynas Kasčiūnas, "Ar Rusija vis dar gali kelti grèsmę posovietiniu valstybiu saugumui?" // http://www.delfi.It (accessed March 02, 2009). On the activity see Gintaras Visockas, "Rusija aktyvina žvalgybinę veikla, Seimo NSK pirmininko pastabos," Valstiečiu laikraštis 6 (2000 01 22): 2. 
to fight globalisation, wastes time. There is no need to say rude words about EU, it should be improved and have soul added as well. The most important thing is to find and to learn about the things that unite people and nations spiritually and culturally. The leaders of modern Europe who are afraid of mentioning the protection of Christian heritage in the Constitution of EU leads the EU to alienation. In the vision of belief the EU could become a unity of nations.

EU architects have to learn from the mistakes of history, to hear the voices of ex-dissidents and never betray small nations as later they themselves will pay a big price for doing so. Only a strong EU could spread a unity from Scandinavia to the Mediterranean Sea. Side by side with the cherishing of economic and military potential and the heritage of national cultures, the protection of national identity is the condition of EU success.

\section{BIBLIOGRAPHY}

1. "A. Pocius: kai kurios valstybès Lietuvoje kariauja informacini kara" // http://www.delfi.lt (accessed March 02, 2009).

2. Bražènas, Vilius. "Lietuva pasaulinès krizès akivaizdoje." Laisvas laikraštis 5 (2007 03 08-22).

3. Buonomo, Vencenzo. L'unita dell'Europa. Tra integrazione e tutela delle identita' [The unity of Europe. Between the protection of integration and identity] (Roma, 2006). La relazione del Profesore alla Conferenza a Kaunas il 10 novembre 2006. [The presentation of Prof. Vencenzo Buonomo at Kaunas conference 1011 2006].

4. Darbo migracijos ypatumai - veiksniai, pasekmès ir tendencijos - Kauno mieste (Kaunas: Spaudos namai, 2007).

5. Deksnys, Marius, and Paulius Tamulionis. "Europos Sajungai - miglota Lietuvos ūkio strategija." Lietuvos rytas 212 (2001 09 11).

6. Endriukaitis, Algirdas. "Atsišaukimas, Rankraštis." (2005 01 31).

7. "Europa skaldo Rusija" // http://www.delfi.lt (accessed March 02, 2009).

8. "JAV žvalgybos vadovas sunerimęs dèl rusu šnipinèjimo." Elta (2007 03 29).

9. Kairys, Feliksas. "Žodžiai smèlyje." Naujasis Dienovidis 20 (1994 05 20).

10. Kasčiūnas, Laurynas. "Ar Rusija vis dar gali kelti grèsmę posovietiniu valstybiu saugumui?" // http://www.delfi.lt (accessed March 02, 2009).

11. Kasčiūnas, Laurynas. "Didelis nerimas." Valstiečiu laikraštis 43 (2000 0530 ).

12. Kubilius, Vytautas. "Ar ilgai tvers mūsu Nepriklausomybė?" Dienovidis 7 (1995 $0218)$. 
13. Kūrys, Pranas, ed. Suvienytuju Naciju Organizacijos Istatai. Tarptautinio Teismo statutas (Vilnius: Mintis, 1981).

14. Landsbergis, Vytautas. "ES neturi europietiškos politikos Rusijos atžvilgiu. Kalba Europos Parlamento mažojoje plenarineje sesijoje spalio $11 \mathrm{~d}$." XXI amžius 19 (2006 11.15).

15. Landsbergis, Vytautas. "Vejantis prarastą laiką." Dienovidis 29 (2000 12 821).

16. Lietuvos Respublikos Seimo Europos informacijos biuras. Sutartis dèl Konstitucijos Europai // http://www.eic.Irs.It/index.php?1959708497 (accessed March 02, 2009).

17. Maceina, Antanas. Asmuo ir istorija. Žmogaus istoriškumo prasmè ir vertè (Kaunas, 1992).

18. Paškevičius, Juozas. "Melo kojos trumpos, arba kam reikalinga Europos Sajunga?" Laisvas laikraštis 11 (2003 05 22-06 05).

19. Pečeliūnienè, Lina. "Europos Sajunga geriau už "šventaji kara"." XXI Amžius 13 (2002 02 15).

20. Petrilli, Gino. "Le radici comuni cristiane della fede nello spirito europeo" [Common Christian roots in religion and European spirit]. In: Pontifical Lateran University, Catholic University of Lublin. The Common Christian Roots of the European Nations (An International Colloquium in the Vatican, Florence, 1982).

21. Rubavičius, Vytautas. "Gynybinis klausimas - nacionalinio tapatumo savikūra." Baltijos kelias 11 (2006 07.04).

22. Terleckas, Antanas. "Sąmokslas prieš Lietuva, skaitytoju nuomonès apie Prezidento rinkimus?" Valstiečiu laikraštis 99 (1997 12 13).

23. Visockas, Gintaras. "Rusija aktyvina žvalgybinę veiklą, Seimo NSK pirmininko pastabos." Valstiečiu laikraštis 6 (2000 01 22).

24. Voverienè, Ona. "Po didelio triukšmo priedanga dar vienas bandymas užvaldyti valstybę." Lietuvos Aidas 92 (2007 04 24).

25. "Užsienio šaliu ambasadu atstovai kviečiami i Lietuvos-Latvijos pasieni." BNS (2006 11 28) // http://www.politika.It/index.php?cid=9329\&new_id=247027 (accessed March 02, 2009).

26. Why the European Union? //

http://Europa.eu/abc/12lessons/lesson_1/index_en.htm (accessed March 02, 2009).

27. Žaltauskaitè-Žalimienè, Skirgailè. Laisvas asmenu judejjimas pagal Europos Bendrijos Teisę: Isisteigimo teisé (Vilnius: Rosma, 2002). 